Counsellia: Jurnal Bimbingan dan Konseling, 9 (1), $2019 \mid 53$ - 64

Copyright (92019 Universitas PGRI Madiun

ISSN: 2088-3072 (Print) / 2477-5886 (Online)

Available online at: http://e-journal.unipma.ac.id/index.php/JBK

DOI: $10.25273 /$ counsellia.v9i1.3927

\title{
Indicators of professional competencies in research of Guidance and Counseling Teachers
}

\author{
Agus Supriyanto $^{1}$, Sri Hartini' ${ }^{2}$, Syamsudin ${ }^{3}$, Anwar Sutoyo ${ }^{4}$ \\ ${ }^{1}$ Fakultas Keguruan dan Ilmu Pendidikan, Universitas Ahmad Dahlan, Yogyakarta \\ agus.supriyanto@bk.uad.ac.id \\ ${ }^{2}$ Fakultas Keguruan dan Ilmu Pendidikan, Universitas Ahmad Dahlan, Yogyakarta \\ sri.hartini@bk.uad.ac.id \\ ${ }^{3}$ Fakultas Keguruan dan Ilmu Pendidikan, Universitas Ahmad Dahlan, Yogyakarta \\ syamsudin@bk.uad.ac.id \\ ${ }^{4}$ Fakultas Ilmu Pendidikan, Universitas Negeri Semarang, Semarang \\ anwarsutoyo@mail.unnes.ac.id
}

\begin{abstract}
Competence counselor in guidance and counseling research needs to be developed through understanding, planning, implementing, and utilizing research results. The purpose of the study was to design indicators of counselor competency in guidance and counseling research. The type of research is qualitative with literature study design. Primary documents through books, journals, scientific articles, and relevant policies for indicator development from the competence of school counselors in research. Qualitative data analysis with the form of social policy analysis through the process of data reduction, data presentation, and data inference. The findings reveal that four indicators were understanding various types and methods of research, ability to design research, conduct research, and use research results by accessing journals of education and guidance and counseling. Each indicator has a sub indicators that need to be tested. Hope in the future is reveal the level or evaluation of the competence of school counselors in guidance and counseling research.
\end{abstract}

Keywords: counselor competence, research, guidance and counseling

\section{INTRODUCTION}

Education aims to improve the quality of students, so that it becomes complete, integrated, and balanced, in accordance with competency standards (Ifdil, 2010).

School counselors have a professional role to be involved in implementing education in schools
(Reiner, Colbert, \& Pérusse, 2009).

The role of school professionals is to link work with the aim of improving schools (Dahir \& Stone, 2009). Implementation of education provided by school counsellors through guidance and counseling services as help to students to provide information and planning for 
the (Myrick, 2011). In the era of disruption 4.0, counselors have a role to use information or approaches to guidance and counseling to students based on research. Accountability and academic performance of students have forced the counsellor to examine the role of school counselors in promoting academic success and student school completion through counseling and guidance research (White\& Kelly, 2011). Guidance and counseling research conducted by school counselors has benefits for designing needs, problems, prevention programs, and interventions for students. Counseling interventions produce considerable effects for students in the fields of discipline, problem solving, and increasing career knowledge (Whiston \& Quinby, 2009).

Facts show the level of understanding counselors are in a high category $(71 \%)$ or have understanding of professional competence counselor guidance and counseling services (Malik, 2015). The reality is that the professional competence of the counselor has a fairly positive category (Setyoningtyas, Mugiarso, \& Nusantoro, 2014). The results of the next study were most of the teachers were guidance and counseling has carried out activities that can improve professional competence, but still no one has done research in counseling and guidance (Nurrahmi, 2015). One obstacle to improving the ability of counselors in guidance and counseling research is the lack of guidelines for developing research competencies (Wester \& Borders, 2014).

School counselors are educators who have competence as educators. According to Baharun (2017) School counselor competencies include pedagogical competence, personal competence, social competence, and professional competence. The competency of school counselors is an ability that needs to be developed by counselors in the context of self-development of counselors to help students. According to Bhakti (2015), several ways to develop counselor professional competencies with 
various activities such as seminars, workshops, training, and research. Basic competencies are needed for the counselor's self-development (Hidayah, 2012).

The Minister has arranged that counselors understand various types and methods of research, are able to design guidance and counseling research, carry out guidance and counseling research, and utilize the results of research in guidance and counseling (Menteri Pendidikan Nasional, 2008). The competence of the counselor in guidance and counseling research needs to be detailed and developed. This study aims to be able to design indicators of school counselor competence in guidance and counseling research, thus supporting the professional competence of school counselors as educators in Indonesia.

\section{RESEARCH METHOD}

Qualitative research with literature study design is used in research. Qualitative research analyzes data from written documents (Patton, 2005) and allows the performance of developing ideas
(Denzin \& Lincoln, 2008). The results of the study are designed to find relevant indicators of the development of the competence of school counselors in guidance and counseling research. Primary data sources through books, journals, scientific articles, or supporting regulations/ policies.

The instrument used is documentation that contains relevant documents. The analysis used is descriptive qualitative analysis with the type of social policy analysis to describe the indicators of understanding, designing, implementing, and utilizing the results of guidance and counseling research by school counselors. Stages of data analysis through the process of data reduction, data presentation, and data inference. The results of qualitative research has a purpose in the frame of the critical theoretical context of the views of researchers (Kincheloe \& McLaren, 2011), finding a school counselor competencies. 


\section{RESULTS AND DISCUSSION}

The results of the study found that education in Indonesia has a policy on the competence of school counselors in comprehensive guidance and counseling research. The competence of counselors in guidance and counseling research has four indicators: (1) understand the different types and methods of research, (2) design research guidance and counseling, (3) conduct research guidance and counseling, and (4) use of research in guidance and counseling with access to educational journals and guidance and counseling (Menteri Pendidikan Nasional, 2008). The four indicators need to be conceptually reviewed, so sub indicators are found. The conceptual framework seeks to meet the need for a strong approach that is based on deeper interdisciplinary knowledge (Huutoniemi, Klein, Bruun, \& Hukkinen, 2010).

Table 1. Indicators of Competence in Guidance and Counseling Research

\begin{tabular}{|l|l|}
\hline \multicolumn{1}{|c|}{ Variable } & \multicolumn{1}{c|}{ Indicator } \\
\hline Competency of & Understanding the concept of research \\
\cline { 2 - 2 } $\begin{array}{l}\text { Counselors in } \\
\text { Research Guidance } \\
\text { and Counseling }\end{array}$ & Ability to design research \\
\cline { 2 - 2 } & Ability to implement research \\
\cline { 2 - 2 } & Utilization of research findings \\
\hline
\end{tabular}

First, the counselor's understanding of the types and methods of research. This competency has the use of developing the cognitive aspects of the counselor for guidance and counseling research. Understanding has the meaning of understanding or understanding correctly, so that the counselor's understanding is processes and ways for counselors to understand (Fajri, 2009). Counselor's competence about the counselor's understanding of the concept of research guidance and counseling includes (1) school counselor knowledge of traditional experimental designs, quasiexperimental designs that are suitable for field settings, single subject design, survey design, and qualitative design, (2) counselor's understanding of design problems, such as validity, sampling methods, and power, (3) 
knowledge of school counselors about statistical analysis commonly used in counseling research, (4) counselor's understanding of statistical issues, such as role assumptions, hypothesis testing strategies, and confirmation analysis versus exploration, and than (5) the ability of the counselor to carry out computer-assisted analysis, as well as professional writing skills (Heppner, Kivlighan, \& Wamplod, 2008).

Table 2. An Understanding of The Concept of Guidance and Counseling Research

\begin{tabular}{|c|c|c|}
\hline Indicator & Sub Indicator & Descriptors \\
\hline \multirow{24}{*}{$\begin{array}{l}\text { Counselor's } \\
\text { understanding of } \\
\text { research } \\
\text { (Leech\& Onwuegbuzie, } \\
\text { 2010; Heppner, } \\
\text { Kivlighan, \& Wamplod, } \\
\text { 2008; Ray, Minton, \& } \\
\text { Brown, 2010) }\end{array}$} & \multirow{7}{*}{$\begin{array}{l}\text { Understand-ing the types } \\
\text { and methods of research }\end{array}$} & Experimental Research \\
\hline & & $\begin{array}{l}\text { Quantitative descriptive } \\
\text { research }\end{array}$ \\
\hline & & $\begin{array}{l}\text { Qualitative descriptive } \\
\text { research }\end{array}$ \\
\hline & & Evaluation research \\
\hline & & Mixed Research \\
\hline & & $\begin{array}{l}\text { Action research guidance } \\
\text { and counseling }\end{array}$ \\
\hline & & Single subject Design \\
\hline & \multirow{4}{*}{$\begin{array}{l}\text { Understand-ing of research } \\
\text { design }\end{array}$} & Sampling / subject \\
\hline & & Research instrument \\
\hline & & Research design \\
\hline & & Validity \& reliability \\
\hline & \multirow{3}{*}{$\begin{array}{l}\text { Knowledge of statistical } \\
\text { analysis }\end{array}$} & Descriptive statistics \\
\hline & & Inferential statistics \\
\hline & & Data analysis formula \\
\hline & \multirow{6}{*}{$\begin{array}{l}\text { The ability to use } \\
\text { statistical analysis using } \\
\text { applications }\end{array}$} & T-test \\
\hline & & Product moment \\
\hline & & Alfa cronbanch \\
\hline & & Descriptive \\
\hline & & SEM \\
\hline & & SPSS \\
\hline & \multirow{4}{*}{$\begin{array}{l}\text { Understand-ing of research } \\
\text { issues }\end{array}$} & Hypothesis \\
\hline & & Research question \\
\hline & & Problems \\
\hline & & $\begin{array}{l}\text { The role of counselor in } \\
\text { research }\end{array}$ \\
\hline
\end{tabular}

The second is the ability to design the study guidance and counseling. The ability to design research can be seen from research proposal document. Preparation of research proposals include a draft introduction, literature review, research methods, and references. (Suharsimi, Suhardjono, \& Supardi, 2015). 
Table 3. Ability to Design Research Guidance and Counseling

\begin{tabular}{|c|c|c|}
\hline Indicator & Sub Indicator & Descriptors \\
\hline \multirow{26}{*}{$\begin{array}{l}\text { Ability to design } \\
\text { research }\end{array}$} & \multirow{7}{*}{$\begin{array}{l}\text { Introduction } \\
\text { design }\end{array}$} & Background \\
\hline & & Problems identification \\
\hline & & Scope of problem \\
\hline & & Title of research \\
\hline & & Formulation of the problem \\
\hline & & Research purposes \\
\hline & & Benefits of research \\
\hline & \multirow{5}{*}{$\begin{array}{l}\text { Literature review } \\
\text { Design }\end{array}$} & Discussion of research variables \\
\hline & & Definition \\
\hline & & $\begin{array}{l}\text { Indicators / characteristics / } \\
\text { stages of the research variable }\end{array}$ \\
\hline & & Framework of thinking \\
\hline & & Hypothesis /research question \\
\hline & \multirow{6}{*}{$\begin{array}{l}\text { Research Methods } \\
\text { Design }\end{array}$} & Method used \\
\hline & & Subject / population and sample \\
\hline & & Instruments used \\
\hline & & Research procedure \\
\hline & & Validity and reliability \\
\hline & & Data analysis \\
\hline & \multirow[t]{6}{*}{ Draft References } & The authors name \\
\hline & & Citations \\
\hline & & Year Citation \\
\hline & & Title Citation \\
\hline & & Journals \\
\hline & & Books \\
\hline & \multirow{2}{*}{$\begin{array}{l}\text { Research } \\
\text { Instruments } \\
\text { Design }\end{array}$} & Blueprint instrument \\
\hline & & Research instrument \\
\hline
\end{tabular}

The study design helps researchers so that research be carried out effectively and efficiently. The specific objectives of the research design are:

a. Provides a framework for design research for individual and team researchers

b. Helping to identify areas of research, projects and programs that are most likely to be academically and practically valuable and realistic

c. Enables various approaches and research methods

d. Provide guidance for systematic research planning

e. Provide guidelines for more rigorous research 
f. Helps develop a solid line of into 3 parts, including formulation argumentation

g. Helping to choose the methods and combinations of methods appropriate

h. Provide a context for positioning research projects and programs relative to other design research

i. And to encourage reflection on the approach adopted (Blessing \& Chakrabarti, 2009). research, research planning and implementation of research (Ray, Minton, \& Brown, 2010). This competency can be seen from a comprehensive research report. Research functions as a blueprint or guide to various decisions (Hays\& Wood, 2011). The research discussion also reports and presents the strength of statistical data (Balkin\& Sheperis, 2011).

The third competency is the ability to carry out research. Research study evaluation is divided

Table 4. Ability Implement Guidance and Counseling Research

\begin{tabular}{|c|c|c|}
\hline Indicator & Sub Indicator & Descriptors \\
\hline \multirow{13}{*}{$\begin{array}{l}\text { Ability to carry } \\
\text { out research }\end{array}$} & \multirow{5}{*}{$\begin{array}{l}\text { Results of Research } \\
\text { Data Analysis }\end{array}$} & Validity and reliability test results \\
\hline & & The strength of the data analysis \\
\hline & & Evidence of primary data \\
\hline & & $\begin{array}{l}\text { The strength of the statistical } \\
\text { analysis }\end{array}$ \\
\hline & & Proof of instrument \\
\hline & \multirow{4}{*}{$\begin{array}{l}\text { Research } \\
\text { Discussion }\end{array}$} & Discussion on statistical data \\
\hline & & $\begin{array}{l}\text { Strength of discussion of research } \\
\text { results }\end{array}$ \\
\hline & & $\begin{array}{l}\text { Discussion of research with } \\
\text { relevant literature review }\end{array}$ \\
\hline & & Research design \\
\hline & \multirow[t]{2}{*}{$\begin{array}{l}\text { Research } \\
\text { Conclusions }\end{array}$} & $\begin{array}{l}\text { Conclusions in accordance with the } \\
\text { formulation of the problem }\end{array}$ \\
\hline & & $\begin{array}{l}\text { The conclusion is concise, dense, } \\
\text { and clear }\end{array}$ \\
\hline & \multirow{2}{*}{$\begin{array}{l}\text { Suggestions and } \\
\text { Limitations }\end{array}$} & Description of research limitations \\
\hline & & Relevant suggestions \\
\hline
\end{tabular}

Competence utilization of the results of research and writing scientific publications. Research development to prepare findings and 
be published (Hunt, 2011), as well as content analysis results compiled in scientific articles and published in leading counseling journals (Leech \& Onwuegbuzie, 2011). The findings of the research are promoted as part of educational evaluation or Counseling Outcome Research and Evaluation (Hays, 2010). The findings of the research results are published through research institutions or higher education (Flowerdew, 2015).
Preparation of counseling journal articles consists of several parts including title, identity, abstract, keywords, introduction, research methodology, results and analysis, discussion, conclusions and suggestions, awards, and references (Heppner, Kivlighan, \& Wamplod, 2008; Jatmiko, dkk, 2015; Tenopir, dkk, 2010). The author needs to maximize publication articles and be honest with data, co-authors, and editors (Chen, 2011).

Table 5. Utilization of Guidance and Counseling Research Results

\begin{tabular}{|c|c|c|}
\hline Indicator & Sub Indicator & Descriptors \\
\hline \multirow{6}{*}{$\begin{array}{l}\text { Utilization } \\
\text { Guidance } \\
\text { Counseling }\end{array}$} & \multirow[t]{3}{*}{$\begin{array}{l}\text { Use and evaluation } \\
\text { of research results }\end{array}$} & $\begin{array}{l}\text { Utilizing the results of research in } \\
\text { guidance and counseling services }\end{array}$ \\
\hline & & $\begin{array}{l}\text { Evaluation of service activities } \\
\text { from the results of research }\end{array}$ \\
\hline & & $\begin{array}{l}\text { Educational recommendations } \\
\text { from research results }\end{array}$ \\
\hline & \multirow[t]{3}{*}{$\begin{array}{l}\text { Publication of } \\
\text { research results }\end{array}$} & $\begin{array}{l}\text { Ability to compile scientific } \\
\text { articles }\end{array}$ \\
\hline & & $\begin{array}{l}\text { Knowledge of the journal / } \\
\text { publication seminar }\end{array}$ \\
\hline & & $\begin{array}{l}\text { Utilization of research results in } \\
\text { journals/ research seminar }\end{array}$ \\
\hline
\end{tabular}

The role of school counselors as teachers and also as researchers to find something new for the development of education. Research means search, browse or find meaning back repeatedly (Danim \& Darwis, 2003). Research for school counselors has a specific purpose.
The research objective is to obtain empirical data that can be used in formulating, expanding, and verifying theories, and solving problems that exist in life (Kuntjojo, 2009), one of them is solving the problems faced by the counselee and the counselee's personal 
development. The implication of research is to determine the direction in the future (Taneja, Taneja, \& Gupta, 2011).

Counselors have values, attitudes, skills, knowledge, and insights in the field of guidance and counseling professions, one of which is research and publications in the field of guidance and counselling (Suryono, 2016). The hope in the future is that the counselor will gain recognition of the ability and authority as a professional counselor. Counselors who have professionals are counselors who have a set of abilities that support the implementation of professional guidance and counseling services (Hartini, Bhakti, \& Hartanto, 2016). In accordance with the Indonesian Government's policy that counselors carry out system support through independent research, grouping with peers, or collaboratively with experts in universities (Menteri Pendidikan dan Kebudayaan, 2014).

\section{CONCLUSION}

Development of the professional abilities of counselors or guidance and counseling teachers or school counselors indirectly provides assistance to students through the results of guidance and counseling research. The ability of counselors in guidance and counseling research is arranged in the counselors competence in guidance and counseling research. School counselors or guidance and counseling teachers are required to carry out their professional duties through independent research, group research with peers, and collaborative research with experts in universities.

Four competencies of school counselors in guidance and counseling research. First, understanding research concepts about types and methods, design, statistical analysis, relevant issues, and application usage. Second, the ability to design research from the introduction, literature review, research methods, references, and instruments. Third, conducting research. Finally, the use of research results through the use of research results for guidance and counseling services, as well as dissemination to various parties through journals, 
convention forums, scientific forums, print and electronic media rubrics.

\section{REFERENCES}

Baharun, H. (2018). Peningkatan kompetensi guru melalui sistem kepemimpinan kepala madrasah. At-Tajdid: Jurnal Ilmu Tarbiyah, 6(1), 1-26.

Balkin, R. S., \& Sheperis, C. J. (2011). Evaluating and reporting statistical power in counseling research. Journal of Counseling \& Development, 89(3), 268272.

Bhakti, C. P. (2015). Bimbingan Dan Konseling Komprehensif: Dari Paradigma Menuju Aksi. Jurnal Fokus Konseling, 1(2).

Hartini, S., Bhakti, C. P., \& Hartanto, D. (2016, August). MODEL PENGUATAN KOMPETENSI

PROFESIONAL GURU BIMBINGAN DAN

KONSELING (Telaah Model Hipotetik pada Guru Bimbingan dan Konseling di DI Yogyakarta). In Prosiding Seminar Nasional Inovasi Pendidikan.

Blessing, L. T., \& Chakrabarti, A. (2009). DRM, a design research methodology. Springer Science \& Business Media.

Chen, X. P. (2011). Author ethical dilemmas in the research publication

process. Management and Organization Review, 7(3), 423-432.

Dahir, C. A., \& Stone, C. B. (2009). School counselor accountability: The path to social justice and systemic change. Journal of Counseling \& Development, 87(1), 12-20.

Danim, S., \& Darwis (2003) Metode Penelitian Kebidanan Prosedur, Kebijakan, dan Etik. Jakarta : Penerbit Buku Kedokteran EGC.

Denzin, N. K., \& Lincoln, Y. S. (2008). Introduction: The discipline and practice of qualitative research.

Fajri, E. M. (2009). Zul, and Ratu Aprilia Senja. Kamus Lengkap Bahasa Indonesia,. Surabaya: Difa Publisher.

Flowerdew, J. (2015). Some thoughts on English for research publication purposes (ERPP) and related issues. Language Teaching, 48(2), 250-262.

Hays, D. G. (2010). Introduction to counseling outcome research and evaluation. Sage Journal: Counseling Outcome Research and Evaluation, 1(1), 1-7.

Heppner, P.P., Wampold, B.E., \& Kivlighan Jr., D.M. (2008). Reserach Design in Counseling. Belmont: Thomson Brooks/ Cole

Hidayah, N. (2012). Process-Audit dalam Penyelenggaraan Pendidikan Akademik 
Jenjang S-1 Bimbingan dan Konseling. Jurnal

Pendidikan dan

Pembelajaran (JPP), 17(2), 129-139.

Hunt, B. (2011). Publishing qualitative research in counseling journals. Journal of Counseling \& Development, 89(3), 296300.

Huutoniemi, K., Klein, J. T., Bruun, H., \& Hukkinen, J. (2010). Analyzing interdisciplinarity: Typology and indicators. Research Policy, 39(1), 79-88.

Ifdil, I. (2010). Pendidikan Karakter dalam Bimbingan dan Konseling. Pedagogi: Jurnal Ilmu Pendidikan, 10(2), 5561.

Jatmiko, W., dkk. (2015). Penulisan Artikel Ilmiah. Jakarta: Universitas Indonesia

Kincheloe, J. L., \& McLaren, P. (2011). Rethinking critical theory and qualitative research. In Key works in critical pedagogy (pp. 285326). Brill Sense.

Kuntjojo, D. (2009). Metodologi Penelitian. Universitas

Nusantara PGRI Kediri. Kediri.

Leech, N. L., \& Onwuegbuzie, A. J. (2010). Guidelines for conducting and reporting mixed research in the field of counseling and beyond. Journal of Counseling \& Development, 88(1), 61-69.
Leech, N. L., \& Onwuegbuzie, A. J. (2011). Mixed research in counseling: Trends in the literature. Measurement and Evaluation in Counseling and Development, 44(3), 169-180.

Malik, A. A. (2015). Tingkat Pemahaman Konselor Tentang Kompetensi Professional dalam Pelayanan Bimbingan dan Konseling. Indonesian Journal of Guidance and Counseling: Theory and Application, 4(2).

Menteri Pendidikan Nasional. (2008). Permendiknas No. 27 Tahun 2008 tentang Standar Kualifikasi Akademik dan Kompetensi Konselor. Jakarta: Depdiknas.

Menteri Pendidikan dan Kebudayaan. (2014). Permendikbud No. 111 Tahun 2014 tentang SBimbingan dan Konseling pada Pendidikan Dasar dan Menengah. Jakarta: Depdikbud.

Myrick, R. D. (2011). Developmental guidance and counseling: A practical approach. Educational Media Corporation, PO Box 21311, Minneapolis, MN 55421.

Nurrahmi, H. (2015). Kompetensi profesional guru bimbingan dan konseling. AlHikmah, 9(1).

Patton, M. Q. (2005). Qualitative research. Encyclopedia of statistics in behavioral science. 
Ray, D. C., Minton, C. A. B., Schottelkorb, A. A., \& Brown, A. G. (2010). Single- case design in child counseling research: Implications for counselor education. Counselor

Education and Supervision, 49(3), 193-208.

Reiner, S. M., Colbert, R. D., \& Pérusse, R. (2009). Teacher perceptions of the professional school counselor role: A national study. Professional School Counseling, 12(5), 2156759 X0901200507.

Setyoningtyas, R., Mugiarso, H., \& Nusantoro, E. (2014). Persepsi Guru BK tentang Kompetensi Konselor di Sekolah Dasar Swasta Kota Semarang. Indonesian

Journal of Guidance and Counseling: Theory and Application, 3(2).

Suharsimi, A, Suhardjono, \& Supardi. (2015). Penelitian Tindakan Kelas. Jakarta: Bumi Aksara

Suryono, B. (2016). PUBLIC TRUST DAN PROFESI BK BERMARTABAT MENUJU KARAKTER KONSELOR YANG

DIBUTUHKAN. Counsellia: Jurnal Bimbingan dan Konseling, 2(1).

Taneja, S. S., Taneja, P. K., \& Gupta, R. K. (2011). Researches in corporate social responsibility: A review of shifting focus, paradigms, and methodologies. Journal of Business Ethics, 101(3), 343364.

Tenopir, C., Allard, S., Bates, B., Levine, K. J., King, D. W., Birch, B., ... \& Caldwell, C. (2010). Research Publication Characteristics and Their Relative Values: A.

Wester, K. L., \& Borders, L. D. (2014). Research competencies in counseling: A Delphi study. Journal of Counseling \& Development, 92(4), 447-458.

Whiston, S. C., \& Quinby, R. F. (2009). Review of school counseling outcome research. Psychology in the Schools, 46(3), 267-272.

White, S. W., \& Kelly, F. D. (2010). The school counselor's role in school dropout prevention. Journal of Counseling \& Development, 88(2), 227-235. 